\title{
Ticks on buffaloes (Bubalus bubalis) in the state of Rio de Janeiro, Brazil
}

\author{
Carrapatos em búfalos (Bubalus bubalis) do estado do Rio de Janeiro, Brasil \\ Fabíola do Nascimento Corrêa ${ }^{1 *}$; Nathalie Costa da Cunha ${ }^{2}$; Charles Passos Rangel ${ }^{1}$; Adivaldo Henrique da Fonseca ${ }^{1}$ \\ ${ }^{1}$ Laboratório de Doenças Parasitárias, Departamento Epidemiologia e Saúde Pública, Instituto de Veterinária, \\ Universidade Federal Rural do Rio de Janeiro - UFRRJ, Seropédica, RJ, Brasil \\ ${ }^{2}$ Laboratório de Vetores, Departamento de Ciências Biológicas, Escola Nacional de Saúde Pública Sérgio Arouca, \\ Fundação Oswaldo Cruz, Rio de Janeiro, RJ, Brasil \\ Received September 15, 2011 \\ Accepted October 19, 2011
}

\begin{abstract}
Some tick species have been described parasitizing buffaloes, but reports from Brazil are rare. This study aimed to ascertain the species of ticks that parasitize buffaloes in the state of Rio de Janeiro. Seventeen farm properties were visited between June 2008 and December 2009, and buffaloes were inspected in relation to infestation. The ticks were identified and a semi-structured questionnaire on parasitism and treatment against ticks was filled out through interviews with the owners. The species identified were Rhipicephalus (Boophilus) microplus, Dermacentor nitens and Amblyomma cajennense. It was noted that $82.3 \%$ (14/17) of the properties visited presented animals infested with ticks, although $76.5 \%$ (13/17) had been administering acaricide treatment. Buffaloes in the state of Rio de Janeiro are often parasitized by ticks, especially in the larval and nymph stages.
\end{abstract}

Keywords: Buffaloes, ticks, Rhipicephalus, Amblyomma, Dermacentor.

\section{Resumo}

Algumas espécies de carrapatos foram descritas parasitando bubalinos, porém são raros os relatos no Brasil. $\mathrm{O}$ presente trabalho teve como objetivo conhecer as espécies de carrapatos que parasitam bubalinos no estado do Rio de Janeiro. Dezessete propriedades foram visitadas de junho de 2008 a dezembro de 2009 e os bubalinos foram inspecionados para verificar infestação. Os carrapatos foram identificados e um questionário semi estruturado sobre o parasitismo e o tratamento contra carrapatos foram preenchidos por meio de entrevista com os proprietários. Foram identificadas as espécies Rhipicephalus (Boophilus) microplus, Dermacentor nitens e Amblyomma cajennense. Foi observado que $82,3 \%$ (14/17) das propriedades visitadas apresentavam animais parasitados por carrapatos, embora 76,5\% (13/17) realizassem tratamento acaricida. Búfalos do estado do Rio de Janeiro são frequentemente parasitados por carrapatos, principalmente nos estágios de larvas e ninfas.

Palavras-chave: Búfalos, carrapatos, Rhipicephalus, Amblyomma, Dermacentor.

Parasitism by ticks is highly important because of the damage they cause to their hosts, direct debilitating effects, as well as transmission of the causal agents of babesiosis and anaplasmosis. They also create extra production costs due to higher use of acaricides, labor and control equipment (JONGEJAN; UILENBERG, 2004). Buffaloes are infested by ticks, although with lower intensity of infestation than is observed in cattle (NITHIKATHKUL et al., 2002). In a study in India, Miranpuri (1988) found 19 species of ticks parasitizing buffaloes, including Amblyomma testudinarium,

\footnotetext{
*Corresponding author: Adivaldo Henrique da Fonseca

Laboratório de Doenças Parasitárias, Departamento Epidemiologia e Saúde Pública, Instituto de Veterinária, Universidade Federal Rural do Rio de Janeiro - UFRRJ, BR 465, Km 07, Bairro Ecologia, CEP 23890-000, Seropédica, RJ, Brasil e-mail: adivaldo@ufrrj.br
}

Nosomma monstrosum, five species of the genus Hyalomma, nine of the genus Haemaphysalis and three of the genus Rhipicephalus. Rhipicephalus (B.) microplus was the most prevalent species among all the ticks and was collected throughout the year except in January and February. The incidence of $R$. (B.) microplus in northeastern India was $75.26 \%$ and the incidences of Anaplasma marginale and Babesia bigemina were $6.2 \%$ and $2.6 \%$. The incidence of $R$. (B.) microplus in northwestern India was $22.17 \%$ and the incidences of $A$. marginale and B. bigemina were $14.9 \%$ and 4.7\% respectively. Theileria spp. and Trypanosoma spp. were not found on buffaloes on any farm (MIRANPURI, 1988). In Cuba, $R$. (B.) microplus was found on $94.8 \%$ of the calves, while it was somewhat infrequent among adults $(27.7 \%)$. The infestation rate was significant among the calves (19.7 ticks/animal). The 
ectoparasites were located on the ventral area and ears of the calves, while among adults they were observed on the perineal area (OBREGÓN et al., 2010). In Brazil, there have only been a few reports about parasitism by ticks among buffaloes. Rocha et al. (1969) found natural infestation by $R$. (B.) microplus and Dermacentor nitens on nine buffaloes in the state of São Paulo, mainly on body regions presenting thin skin and short hair. In the state of Mato Grosso do Sul, weekly collections of $R$. (B.) microplus from buffaloes revealed that $74.7 \%$ were at the larval stage, $21.3 \%$ were nymphs and $4.0 \%$ were adults, as reviewed by Gomes (2007). The state of Rio de Janeiro currently has 5,726 buffaloes (IBGE, 2011) and there are no studies on ectoparasites in this population. This study aimed to survey the species of ticks infesting buffaloes in the state of Rio de Janeiro.

Seventeen farm properties were selected, with at least one per microregion with buffalo breeding in the state of Rio de Janeiro, as surveyed by IBGE (2011). Thus, between June 2008 and December 2009, farm properties located in the municipalities of Itaguaí, Casimiro de Abreu, Cachoeiras de Macacu, Rio Claro (two properties), Barra do Piraí, Campos dos Goytacazes (two properties), Vassouras, Teresópolis, Rio das Ostras, Itaboraí, Araruama, Macaé, Miracema, Rio de Janeiro and Cantagalo were visited. A total of 316 buffaloes were inspected visually to ascertain occurrences of infestation. If accessible, according to the possibility of restraining the animals, the ticks found were removed for later identification under a stereomicroscope, using the taxonomic key of Barros-Battesti et al. (2006). During the visits to these farm properties, interviews were conducted in order to fill out a semistructured questionnaire about the presence or absence of ticks and any control system in each establishment. The protocol of Ethical Principles for Animal Research of the Brazilian College of Animal Experimentation was followed during this study.

One hundred and four ticks were collected and identified as nymphs or adults of the species $R$. (B.) microplus, $D$. nitens and Amblyomma cajennense. Although this last species is known to be a tick that parasitizes a wide range of host species, it has not been encountered in previous reports on tick parasitism among buffaloes in Brazil. On all the farms visited, the buffalos were seen to be living with some other domestic animals. Horses, dogs and cattle were found in proportions of $94.4 \%, 83.3 \%$ and $77.7 \%$, respectively. We found a greater degree of parasitism among young animals, with predominance of tick larvae and nymphs.

Through the questionnaire conducted, it was found that on four farm properties (23.6\%), no treatment against ticks had been applied to the animals. On all the other properties, applications of ivermectin $(41.2 \%)$, acaricide baths $(11.8 \%)$ or both procedures $(23.6 \%)$ were made. It was also observed that $41.2 \%(7 / 17)$ of the properties were applying acaricide treatment every six months, $5.9 \%(1 / 17)$ every four months and $5.9 \%$ every two months, while $23.5 \%$ (4/17) of the properties performed sporadic treatments. However, although 13 of the 17 properties (76.5\%) performed acaricide treatments, $82.3 \%(14 / 17)$ of them presented infested animals. This may have been due to incorrect treatments, lack of strategy or misapplication of acaricides, among other factors. Such situations may also lead to tick resistance to the product used (ROCHA et al., 2006). Moreover, it is of interest to highlight that the owners of the animals often reported that there were no ticks in the herd, even when the infestation was visible to us. There were also animal handlers who reported the presence of ticks on animals on which we only observed lice. These incidents demonstrate lack of knowledge about the species, sizes and stages of ectoparasites that may infest the stock, which will certainly impair effective treatments against the ticks that affect buffaloes in the state of Rio de Janeiro.

It is important to know which tick species parasitize buffaloes and what can be done to control them, since ticks are vectors for numerous etiological agents of health importance and buffaloes may participate in maintaining these agents in nature. Studies on the implications of parasitism by ticks on the productivity of buffalo herds should also be encouraged.

\section{References}

Barros-Battesti DM, Arzua M, Bechara GH. Carrapatos de Importância Médico-Veterinária da Região Neotropical - Um guia ilustrado para identificação de espécies. São Paulo: Vox/ICTTD-3/Butantan, 2006. 223 p.

Gomes RA. Resposta Imune-humoral de búfalos (Bubalus bubalis) infectados naturalmente por Babesia bovis, B. bigemina e Anaplasma marginale. [Dissertação]. Jaboticabal: Universidade Estadual Paulista; 2007.

Instituto Brasileiro de Geografia e Estatística - IBGE [online]. [cited 2011 Jan 14]. Available from: http://www.ibge.gov.br/estadosat/temas. php?sigla=rj\&tema=pecuaria2009.

Jongejan F, Uilenberg G. The global importance of ticks. Parasitology 2004; 129:S3-S14.

Miranpuri GS. Ticks parasitising the Indian buffalo (Bubalus bubalis) and their possible role in disease transmission. Vet Parasitol 1988; 27(34): 357-362. PMid:3369083. http://dx.doi.org/10.1016/03044017(88)90050-7

Nithikathkul C, Polseela P, Changsap B, Leemingsawat S. Ixodid ticks on domestic animals in Samut Prakan Province, Thailand. Southeast Asian J Trop Med Public Health 2002; 33(S3):41-44. PMid:12971472.

Obregón D, Rodríguez Diego JG, Roque E, Alemán Y. Rhipicephalus (Boophilus) microplus (Acari: Ixodidae) en búfalo (Bubalus bubalis), en Cuba. Rev Salud Anim 2010; 32(2): 132-134.

Rocha UF, Serra OP, Grock R, Serra RG. Infestação natural de búfalos, Bubalus bubalis L., 1758 dos Estados de Sáo Paulo e Minas Gerais, Brasil, por Boophilus microplus (Canestrini, 1887) e por Anocentor nitens (Neumann,1897), Acari, Ixodidae. Arq Inst Biol 1969; 36: 197-199.

Rocha CMBM, Oliveira PR, Leite RC, Cardoso DL, Calic SB, Furlong J. Percepção dos produtores de leite do município de Passos, MG, sobre o carrapato Boophilus microplus (Acari: Ixodidae), 2001. Cienc Rural 2006; 36(4):1235-1242. 